\title{
Migraine with aura as the predominant phenotype in a family with a PRRT2 mutation
}

\author{
Una-Marie Sheerin • Maria Stamelou • Gavin Charlesworth - Tamara Shiner • \\ Sian Spacey $\cdot$ Enza-Maria Valente $\cdot$ Nicholas W. Wood $\cdot$ Kailash P. Bhatia
}

Received: 19 July 2012/Revised: 2 November 2012/ Accepted: 3 November 2012/Published online: 24 November 2012

(c) Springer-Verlag Berlin Heidelberg 2012

Dear Sirs,

Paroxysmal kinesigenic dyskinesia (PKD) is characterized by paroxysms of dystonic, choreic, ballistic, or athetoid movements. Attacks usually commence during childhood or early adulthood, typically lasting a few seconds to a few minutes, and they can occur up to 100 times daily. Attacks usually respond to low-dose carbamazepine [1]. Mutations in PRRT2 have been identified as a cause of autosomal dominant PKD [2] and replicated in other studies [3-7]. It remains important to report the clinical characteristics of genetically defined families in order to fully describe the clinical syndrome, including the presence of additional associated features beyond the movement disorder.

In a large Caucasian family with PKD (Fig. 1), a detailed neurological history and clinical examination were undertaken. Sanger sequencing of PRRT2 was performed. Three individuals have PKD alone, and three individuals

U.-M. Sheerin · G. Charlesworth · N. W. Wood

Department of Molecular Neuroscience,

UCL Institute of Neurology,

Queen Square, London WC1N 3BG, UK

e-mail: u.sheerin@ucl.ac.uk

G. Charlesworth

e-mail: gavin.charlesworth@ucl.ac.uk

N. W. Wood

e-mail: n.wood@ucl.ac.uk

M. Stamelou · T. Shiner · K. P. Bhatia ( $₫)$

Sobell Department of Motor Neuroscience and Movement

Disorders, UCL Institute of Neurology, Queen Square,

London WC1N 3BG, UK

e-mail: k.bhatia@ucl.ac.uk

M. Stamelou

e-mail: m.stamelou@ucl.ac.uk have PKD and infantile convulsions (IC). Two individuals had isolated IC, whilst two other individuals had at least one adolescent seizure but no movement disorder. The age of onset for the movement disorder ranged between 3 and 30 years. Infantile convulsions occurred between the age of 6 and 12 months. In all cases, PKD attacks were choreic or dystonic in nature, lasting less than a minute, and responded well to carbamazepine. Attacks were provoked by sudden movements in all, with stress in II:10 and III:9. Four individuals were treated with low-dose carbamazepine and/or phenytoin for $\mathrm{PKD} / \mathrm{IC}$, which abolished symptoms of the movement disorder. Neurological examination was normal (Table 1).

Sanger sequencing of PRRT2 revealed the recognized pathogenic (c.649_650InsC p.P217fsX7) heterozygous mutation [2-7] in all eight clinically affected individuals as well as in three of the seven clinically unaffected individuals (Fig. 1). PRRT2 mutations are unlikely to be the

\author{
T. Shiner \\ e-mail: tamarashiner@gmail.com \\ S. Spacey \\ Department of Neurology, St Paul's Hospital, \\ Burrard Street, Vancouver, BC, Canada \\ e-mail: spacey@mail.ubc.ca \\ E.-M. Valente \\ Department of Neurology, Istituto CSS-Mendel \\ Viale Regina Margherita, Rome, Italy \\ e-mail: e.valente@css-mendel.it \\ N. W. Wood \\ UCL Genetics Institute, University College London, \\ Gowers Street, London WC1E 6BT, UK
}


Table 1 Clinical descriptions and genotyping results for family members

\begin{tabular}{|c|c|c|c|c|c|c|c|}
\hline Individual & Gender & $\begin{array}{l}\text { Age } \\
\text { currently } \\
\text { (years) }\end{array}$ & $\begin{array}{l}\text { Phenotype } \\
\text { (age at onset } \\
\text { indicated in } \\
\text { brackets) }\end{array}$ & Treatment & $\begin{array}{l}\text { Description of } \\
\text { IC/PKD attacks }\end{array}$ & $\begin{array}{l}\text { Past medical history/ } \\
\text { additional features }\end{array}$ & Genotype \\
\hline $\mathrm{I}: 2$ & $\mathrm{~F}$ & 85 & Asymptomatic & N/A & & $\begin{array}{l}\text { Continuous left sided } \\
\text { choreiform movements } \\
\text { for a year during an } \\
\text { intercurrent illness } \\
\text { diagnosed as rheumatic } \\
\text { fever. Cardiac valve } \\
\text { replacement for } \\
\text { rheumatic-fever related } \\
\text { valvulopathy. Migraine } \\
\text { with visual aura and } \\
\text { transient expressive } \\
\text { dysphasia }\end{array}$ & p.P217fsX7 \\
\hline II:4 & $\mathrm{F}$ & 52 & $\begin{array}{l}\text { IC (6 months) } \\
\text { PKD (5 years) }\end{array}$ & $\begin{array}{l}\text { Phenytoin for IC. } \\
\text { Carbamazepine } \\
200 \text { mg od for } \\
\text { PKD attacks } \\
\text { commenced age } \\
12 \text { thereafter } \\
\text { asymptomatic }\end{array}$ & $\begin{array}{l}\text { Several IC: } 6 \text { afebrile } \\
\text { generalized tonic-clonic } \\
\text { seizures. Dystonic } \\
\text { posturing of left arm and } \\
\text { left side of the face, and } \\
\text { preceded by aura } \\
\text { consisting of left arm } \\
\text { paraesthesia }\end{array}$ & Migraine with visual aura & p.P217fsX7 \\
\hline III: 1 & M & 15 & $\begin{array}{l}\text { IC (from } \\
6-18 \text { months) } \\
\text { PKD (3 years) }\end{array}$ & $\begin{array}{l}\text { Carbamazepine } \\
600 \mathrm{mg} \text { od for } \\
\text { PKD attacks } \\
\text { thereafter } \\
\text { asymptomatic }\end{array}$ & $\begin{array}{l}\text { Aged } 3 \text { years legs turned } \\
\text { outwards whilst running. } \\
\text { Aged } 8 \text { years brief } \\
\text { episodes of choreiform } \\
\text { movements of both legs } \\
\text { and left arm, preceded } \\
\text { by a "tingling" } \\
\text { sensation in his legs }\end{array}$ & & p.P217fsX7 \\
\hline II:6 & $\mathrm{F}$ & 61 & PKD (30 years) & N/A & $\begin{array}{l}\text { Several brief episodes of } \\
\text { involuntary movements } \\
\text { of one arm and facial } \\
\text { dystonic posturing }\end{array}$ & $\begin{array}{l}\text { Frequent migraines with } \\
\text { visual aura and } \\
\text { accompanied by } \\
\text { transient expressive } \\
\text { dysphasia, treated with } \\
\text { propranolol with good } \\
\text { response }\end{array}$ & p.P217fsX7 \\
\hline III:2 & $\mathrm{F}$ & 25 & $\begin{array}{l}\text { IC ( } 12 \text { months }) \\
\text { PKD ( } 10 \text { years) }\end{array}$ & N/A & $\begin{array}{l}\text { Brief recurrent episodes of } \\
\text { involuntary arm } \\
\text { movements }\end{array}$ & $\begin{array}{l}\text { Migraine with aura } \\
\text { symptoms of transient } \\
\text { expressive dysphasia } \\
\text { and alexia }\end{array}$ & p.P217fsX7 \\
\hline III:3 & $\mathrm{F}$ & 39 & Asymptomatic & N/A & N/A & $\begin{array}{l}\text { Severe frequent migraine } \\
\text { with visual aura since } \\
\text { adolescence, triggered } \\
\text { by exercise, including } \\
\text { episodes associated } \\
\text { with transient } \\
\text { expressive dysphasia } \\
\text { and alexia }\end{array}$ & p.P217fsX7 \\
\hline III:4 & M & 40 & Asymptomatic & N/A & N/A & & Wild type \\
\hline III:5 & $\mathrm{F}$ & 38 & Asymptomatic & N/A & N/A & & Wild type \\
\hline II: 10 & $\mathrm{~F}$ & 61 & PKD (9 years) & $\begin{array}{l}\text { Carbamazepine } \\
\text { (100 mg od) for } \\
\text { PKD attacks }\end{array}$ & $\begin{array}{l}\text { Dystonic posturing of the } \\
\text { head and left arm, } \\
\text { preceded by a sensation } \\
\text { of weakness in the left } \\
\text { foot. Attacks more } \\
\text { frequent pre-menstrually }\end{array}$ & $\begin{array}{l}\text { Migraine with visual aura } \\
\text { since adolescence. } \\
\text { Small cerebral } \\
\text { haemorrhage }\end{array}$ & p.P217fsX7 \\
\hline
\end{tabular}


Table 1 continued

\begin{tabular}{|c|c|c|c|c|c|c|c|}
\hline Individual & Gender & $\begin{array}{l}\text { Age } \\
\text { currently } \\
\text { (years) }\end{array}$ & $\begin{array}{l}\text { Phenotype } \\
\text { (age at onset } \\
\text { indicated in } \\
\text { brackets) }\end{array}$ & Treatment & $\begin{array}{l}\text { Description of } \\
\text { IC/PKD attacks }\end{array}$ & $\begin{array}{l}\text { Past medical history/ } \\
\text { additional features }\end{array}$ & Genotype \\
\hline III:9 & M & 37 & PKD (9 years) & $\begin{array}{l}\text { Carbamazepine } \\
\text { (100 mg od) for } \\
\text { PKD attacks }\end{array}$ & $\begin{array}{l}\text { Dystonic posturing of the } \\
\text { right arm, preceded by } \\
\text { 'strange sensation } \\
\text { spreading down the right } \\
\text { side', lasting } 30 \mathrm{~s} \text {, } \\
\text { occurring up to } 15 \text { times } \\
\text { a day }\end{array}$ & $\begin{array}{l}\text { Migraine with aura and } \\
\text { bladder diverticula }\end{array}$ & p.P217fsX7 \\
\hline III: 10 & $\mathrm{~F}$ & 36 & Asymptomatic & & & $\begin{array}{l}\text { Fallot's tetralogy. } \\
\text { Migraine with visual } \\
\text { aura and expressive } \\
\text { dysphasia }\end{array}$ & p.P217fsX7 \\
\hline II:8 & $\mathrm{F}$ & 58 & $\begin{array}{l}\text { IC (aged } \\
5 \text { months) }\end{array}$ & NT & $\begin{array}{l}\text { Several IC multiple } \\
\text { afebrile generalized } \\
\text { tonic-clonic seizures }\end{array}$ & $\begin{array}{l}\text { Migraine with visual aura } \\
\text { since adolescence, } \\
\text { treated with propranolol }\end{array}$ & p.P217fsX7 \\
\hline III:6 & $\mathrm{F}$ & 30 & IC (6-12 months) & NT & $\begin{array}{l}\text { Several IC: multiple } \\
\text { generalized tonic-clonic } \\
\text { seizures }\end{array}$ & Migraine with visual aura & p.P217fsX7 \\
\hline III:12 & M & 27 & Asymptomatic & & & $\begin{array}{l}\text { Generalized tonic-clonic } \\
\text { and partial seizures } \\
\text { aged } 9 \text { years. Seizures } \\
\text { well controlled on } \\
\text { carbamazepine } 200 \mathrm{mg} \\
\text { bd. MRI brain normal }\end{array}$ & Wild type \\
\hline III:7 & $\mathrm{F}$ & 28 & Asymptomatic & & & $\begin{array}{l}\text { Single generalized tonic- } \\
\text { clonic seizure aged } \\
13 \text { years }\end{array}$ & NT \\
\hline II:2 & M & 45 & Asymptomatic & & & & Wild type \\
\hline III:8 & $\mathrm{F}$ & 20 & Asymptomatic & & & & Wild type \\
\hline III:11 & M & 34 & Asymptomatic & & & & Wild type \\
\hline
\end{tabular}

$P K D$ paroxysmal kinesigenic dyskinesia, $I C$ infantile convulsions, $N / A$ not applicable, $N T$ indicates that the patient was unavailable genetic testing

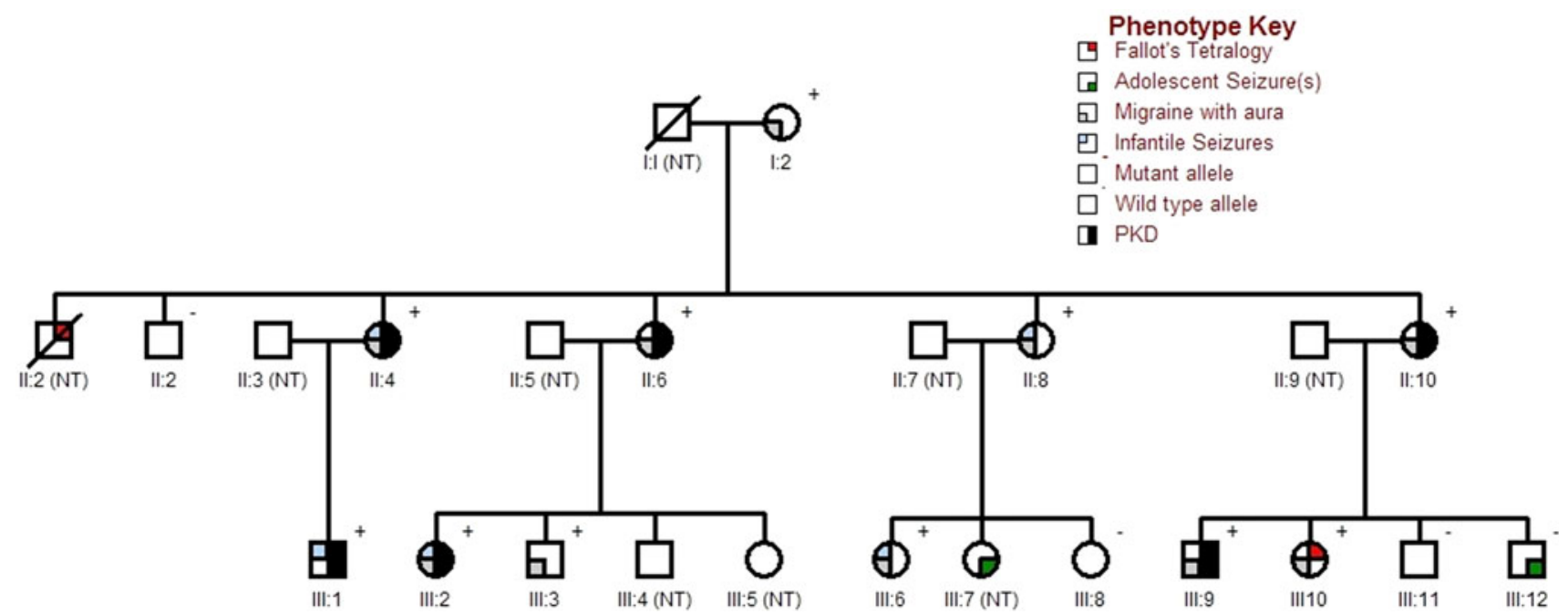

Fig. 1 Pedigree of Family 1. All individuals with symptoms of PKD, PKD and IC, or isolated IC were found to have a frameshift mutation in PRRT2 (c.649_650InsC p.P217fsX7) indicated by a plus symbol; individuals found not to have the mutation are indicated by a minus symbol. Deceased members are marked with a diagonal bar. The phenotype key indicates manifestation of each individual. Individuals who were unavailable for genetic testing are marked $N T$ 
cause of adolescent-onset seizures in this family, as individual III:12 did not carry the mutation. Non-penetrance was observed in three individuals. Migraine with aura, as classified using the International Headache Society diagnostic criteria [8], co-segregated in all but one individual with the p.P217fsX7 mutation, including in three individuals who do not have symptoms of IC/PKD, but was not observed in individuals who did not carry the p.P217fsX7 mutation. Visual aura (positive visual phenomena) was most frequently reported, other types of aura including expressive dysphasia, alexia and alien hand syndrome were also described. Migraine frequency ranged from twice a year to three times a month. Reported triggers included stress, sleep deprivation and exercise. Two individuals were treated with low-dose propranolol for several months, which reduced the frequency and severity of migraine attacks, but did not improve symptoms of the movement disorder.

Previously reported linkage studies for this kindred (family 3, Spacey et al.) [9] generated LOD scores that were not significant for the analysis of PKD alone or $\mathrm{PKD} \pm \mathrm{IC}$. We repeated linkage analysis using Merlin [10], assuming an autosomal dominant mode of inheritance with $80 \%$ penetrance. LOD scores for the PRRT2 mutation and PKD/IC and the PRRT2 mutation and migraine with aura are 1.65 and 2.7, respectively. Several kindreds with hemiplegic migraine and PRRT2 mutations have recently been reported [11]. Migraine (with and without aura) is over-represented in individuals with PRRT2 mutations and clustering of migraine has been identified in small kindred's harboring PRRT2 mutations [12] In this large family, migraine with aura segregates in a Mendelian fashion in nine of 10 individuals with the PRRT2 mutation, the remaining individual is still in adolescence and could still go onto develop migraine. Furthermore, it highlights that in some families, migraine with aura may be the predominant phenotype associated with PRRT2 mutations, which is important to bear in mind when determining whether a patient with $\mathrm{PKD} / \mathrm{IC}$ has a positive family history, to enable appropriate genetic counseling and testing. The association of migraine with PRRT2 mutations raises the question of whether genetic variation in PRRT2 might play a role in susceptibility to 'common' migraine with aura.

Acknowledgments This study was supported by the Medical Research Council and Wellcome Trust disease centre (grant WT089698/Z/09/Z). DNA extraction work was undertaken at University College London Hospitals, University College London, who received a proportion of funding from the Department of Health's National Institute for Health Research Biomedical Research Centres funding.

Conflicts of interest Una-Marie Sheerin is funded by the Medical Research Council (UK). Maria Stamelou has nothing to disclose. Gavin Charlesworth has nothing to disclose. Tamara Shiner is funded by the Wellcome trust. Sian Spacey has nothing to disclose. EnzaMaria Valente has nothing to disclose. Nicholas W Wood is funded Medical Research Council (UK), Wellcome Trust and Parkinson's UK. Kailash $\mathrm{P}$ Bhatia received funding for travel from GlaxoSmithKline, Orion Corporation, Ipsen, and Merz Pharmaceuticals, LLC; serves on the editorial boards of Movement Disorders and Therapeutic Advances in Neurological Disorders; receives royalties from the publication of Oxford Specialist Handbook of Parkinson's Disease and Other Movement Disorders (Oxford University Press, 2008); received speaker honoraria from GlaxoSmithKline, Ipsen, Merz Pharmaceuticals, LLC, and Sun Pharmaceutical Industries Ltd.; personal compensation for scientific advisory board for GSK and Boehringer Ingelheim; received research support from Ipsen and from the Halley Stewart Trust through Dystonia Society UK, and a grant from the Dystonia Coalition and a grant from Parkinson's UK (Ref. number G-1009).

Ethical standard All human study must state that have been approved by the appropriate ethics committee and have therefore been performed in accordance with the ethical standards laid down in the 1964 Declaration of Helsinki.

\section{References}

1. Bruno MK, Hallett M, Gwinn-Hardy K, Sorensen B, Considine E, Tucker S, Lynch DR, Mathews KD, Swoboda KJ, Harris J, Soong BW, Ashizawa T, Jankovic J, Renner D, Fu YH, Ptacek LJ (2004) Clinical evaluation of idiopathic paroxysmal kinesigenic dyskinesia: new diagnostic criteria. Neurology 63:2280-2287

2. Chen WJ, Lin Y, Xiong ZQ, Wei W, Ni W, Tan GH, Guo SL, He J, Chen YF, Zhang QJ, Li HF, Murong SX, Xu J, Wang N, Wu ZY (2011) Exome sequencing identifies truncating mutations in PRRT2 that cause paroxysmal kinesigenic dyskinesia. Nat Genet 43:1252-1255

3. Cao L, Huang XJ, Zheng L, Xiao Q, Wang XJ, Chen SD (2012) Identification of a novel PRRT2 mutation in patients with paroxysmal kinesigenic dyskinesias and c.649dupC as a mutation hot-spot. Parkinsonism Relat Disord 18(5):704-706

4. Lee HY, Huang Y, Bruneau N, Roll P, Roberson ED, Hermann M, Quinn E, Maas J, Edwards R, Ashizawa T, Baykan B, Bhatia K, Bressman S, Bruno MK, Brunt ER, Caraballo R, Echenne B, Fejerman N, Frucht S, Gurnett CA, Hirsch E, Houlden H, Jankovic J, Lee WL, Lynch DR, Mohammed S, Muller U, Nespeca MP, Renner D, Rochette J, Rudolf G, Saiki S, Soong BW, Swoboda KJ, Tucker S, Wood N, Hanna M, Bowcock AM, Szepetowski P, Fu YH, Ptacek LJ (2012) Mutations in the gene PRRT2 cause paroxysmal kinesigenic dyskinesia with infantile convulsions. Cell Rep 1:2-12

5. Li J, Zhu X, Wang X, Sun W, Feng B, Du T, Sun B, Niu F, Wei H, Wu X, Dong L, Li L, Cai X, Wang Y, Liu Y (2012) Targeted genomic sequencing identifies PRRT2 mutations as a cause of paroxysmal kinesigenic choreoathetosis. J Med Genet 49:76-78

6. Liu Q, Qi Z, Wan XH, Li JY, Shi L, Lu Q, Zhou XQ, Qiao L, Wu LW, Liu XQ, Yang W, Liu Y, Cui LY, Zhang X (2012) Mutations in PRRT2 result in paroxysmal dyskinesias with marked variability in clinical expression. J Med Genet 49(2):79-82

7. Wang K, Zhao X, Du Y, He F, Peng G, Luo B (2012) Phenotypic overlap among paroxysmal dyskinesia subtypes: Lesson from a family with PRRT2 gene mutation. Brain Dev [Epub ahead of print]

8. Classification and diagnostic criteria for headache disorders, cranial neuralgias and facial pain (1988) Headache Classification Committee of the International Headache Society. Cephalalgia 8(Suppl 7):1-96 
9. Spacey SD, Valente EM, Wali GM, Warner TT, Jarman PR, Schapira AH, Dixon PH, Davis MB, Bhatia KP, Wood NW (2002) Genetic and clinical heterogeneity in paroxysmal kinesigenic dyskinesia: evidence for a third EKD gene. Mov Disord 17:717-725

10. Abecasis GR, Cherny SS, Cookson WO, Cardon LR (2002) Merlin-rapid analysis of dense genetic maps using sparse gene flow trees. Nat Genet 30(1):97-101

11. Riant F, Roze E, Barbance C, Meneret A, Guyant-Marechal L, Lucas C, Sabouraud P, Trebuchon A, Depienne C, Tournier-
Lasserve E (2012) PRRT2 mutations cause hemiplegic migraine. Neurology [Epub ahead of print]

12. Cloarec R, Bruneau N, Rudolf G, Massacrier A, Salmi M, Bataillard M, Boulay C, Caraballo R, Fejerman N, Genton P, Hirsch E, Hunter A, Lesca G, Motte J, Roubertie A, Sanlaville D, Wong SW, Fu YH, Rochette J, Ptacek LJ, Szepetowski P (2012) PRRT2 links infantile convulsions and paroxysmal dyskinesia with migraine. Neurology [Epub ahead of print] 